\title{
FINANCIAL LEASING IN THE FUNCTION OF ECONOMIC DEVELOPMENT OF BOSNIA AND HERZEGOVINA (STATISTICAL APPROACH)
}

\author{
Slobodan Subotić ${ }^{1}$ \\ Goran Mitrović ${ }^{2}$ ib \\ Vladimir Markovićc
}

DOI: https://doi.org/10.31410/ITEMA.S.P.2020.81

\begin{abstract}
The leasing institution is typical for countries with developed market economies, although it keeps gaining more and more importance in transition countries. Therefore, the research in this paper is focused on the financial leasing market in Bosnia and Herzegovina, as one of the countries undergoing transition process. Its basic features have been assessed, together with determining turnover over the observed ten-year period, both in Bosnia and Herzegovina as a whole and in its respective entities. The research aims to establish to what extent has financial leasing contributed to the development of the small and medium enterprise (SME) sector and the economic development of Bosnia and Herzegovina. Modern statistical methods have been applied to analyze the connection and interdependence of leasing and certain macroeconomic indicators in Bosnia and Herzegovina. For the purpose and in the context of this research, the following indicators, such as the values of leasing, gross domestic product, export, import, and foreign direct investments related to the period from 2009 to 2018 are presented in the respective tables and charts. The analysis is based on the application of descriptive and econometric statistical methods of correlation and regression, as well as on the following statistical packages: IBM SPSS ver. 21, Microsoft XLSTAT. A particular, dedicated segment of the analysis refers to determining the impact of financial leasing on the level of SME investment to classic bank loans. That is, to what extent is financial leasing in the function of investment decision-making of small and medium enterprises in Bosnia and Herzegovina.
\end{abstract}

Keywords: Financial leasing, GDP, Export, Import, FDI, SME.

\section{INTRODUCTION}

$\mathrm{L}$

easing is a distinct form of obtaining fixed assets through the lease. According to International Accounting Standard 17): A lease is an agreement whereby the lessor conveys to the lessee in return for a payment or series of payments the right to use an asset for an agreed period. In its original form, leasing is letting (renting) movable and immovable property to a party, i.e. a new type of contract that has gained its particular economic characteristics in business practice. Since the goods are placed outside the usual forms, being cash and loans, it is said that a lease is a distinct method of financing, based on a particular contract, and with a leasing fee. This method generates preconditions for companies to procure equipment without exhausting depreciation funds and emptying their accounts. Instead of purchasing new equipment using their funds or by loans, companies turn to a leasing

University of East Sarajevo, Faculty of Transportation Doboj, Doboj, Republic of Srpska, B\&H

Drina Insurance a.d. Milici, Republic of Srpska, B\&H

Drina Insurance a.d. Milici, Republic of Srpska, B\&H 
company by practically renting the required equipment for a certain period, under appropriate conditions and respective compensation (Vunjak, 2005).

The research conducted in the paper is related to Financial Leasing Market in Bosnia and Herzegovina and is divided into three parts. The first part of the paper focuses on the financial leasing market in the period from 2009 to 2018. Leasing arrangements in both entities (the Republic of Srpska and the Federation of $\mathrm{BH}$ ) have been determined, as well as total financial leasing arrangements at the Bosnia and Herzegovina level. The annual trend of financial leasing was monitored, accompanied by a tabular and graphical presentation. The second part of the paper contains a statistical analysis of the interdependence of economic indicators (financial leasing, GDP, exports, imports and FDI), based on the application of econometric statistical methods of correlation and regression, obtained with the assistance of statistical software suites: IBM SPSS ver. 21, Microsoft XLSTAT. The final segment of the paper, through comparative analysis assessed the role of leasing in equipment investment of small and medium enterprises in Bosnia and Herzegovina in relation to investing through standard bank loans for the period from 2009 to 2018. The conclusion segment of the paper highlights the key findings and summarized research results.

\section{1. (FINANCIAL) LEASING MARKET IN BOSNIA AND HERZEGOVINA}

In the countries of the Western Balkans, including Bosnia and Herzegovina, the leasing sector has grown despite the lack of appropriate legislation. Although this can be perceived as a temporary relief for credit-laden companies, it is an area of great importance due to the lack of a suitable framework for supervising the consequences for the financial sector (Vukmirović, 2007). Due to the lack of legal regulations on leasing operations, in the BH market, leasing functioned similarly to bank loans until 2007. Small and medium enterprises (SMEs), as well as entrepreneurs, leasing beneficiaries, procured fixed assets and equipment through loans. This was regulated by the current Law on Obligations and Basics of Property-Legal Relations, which were not appropriate for leasing. This type of financing was sometimes more expensive for small and medium enterprises in comparison to standard bank loans, as it obliged users to sign a comprehensive insurance policy. Therefore, in both entities (the Republic of Srpska and the Federation of $\mathrm{BH}$ ), the adoption of the Law on Leasing was inevitable, thus enabling leasing services to transcend from a "quasi-banking" loan into adequate support for the development of small and medium enterprises and entrepreneurship.

In the Republic of Srpska, the Law on Leasing was passed in mid-2007, providing for two types of leasing: (1) operating leasing, (2) financial leasing. According to this Law, the minimum amount of share capital of leasing companies is 250000 Bosnian Convertible Marks (BAM), with the Banking Agency of the Republic of Srpska issuing the respective licenses and performs control and supervision of the operations of lessors. By bringing leasing within the legal framework, leasing services have been regulated as in developed market economies. This has made the leasing business a simpler and cheaper source of financing for small and mediumsized enterprises compared to standard bank loans. The adoption of the Law on Leasing has particularly affected those companies lacking sufficient capital to purchase fixed assets and equipment, or collateral mandatory to secure expensive bank loans.

The Federation of $\mathrm{BH}$ adopted the Law on Leasing at the end of 2008. According to this Law, the Banking Agency of the Federation of BH shall issue licenses and perform supervision and control over the operations of leasing companies within its area of jurisdiction. It should be 
noted that the Law on Leasing in both entities regulates the mandatory payment of value-added $\operatorname{tax}(\mathrm{VAT})$ on interest in any of the financial leasing arrangements.

According to the Central Bank of Bosnia and Herzegovina, in the year 2018, seven leasing companies in Bosnia and Herzegovina had leasing assets of 152.4 million euros, which is an increase of 18.97 million or $14.2 \%$ compared to the year before. The increase in the balance total was achieved by two leasing companies of 24.36 million euros, while four leasing companies registered a decrease in their balance total in the amount of 6.30 million euros, compared to $2017.88 \%$ of the value of the leasing contract is related to financial leasing, and the remaining $12 \%$ relates to operating leasing. The value of leasing operations in 2018 amounted to 98.82 million euros, which is $32.2 \%$ more than in the year 2017. At the end of 2018 , the leasing sector recorded a positive financial result of 1.69 million euros. Three leasing companies reported a loss of 1.23 million euros, and four leasing companies reported a profit of 2.92 million euros (Central Bank of Bosnia and Herzegovina, 2018). From JanuaryDecember 2018, there were no registered lessors based in the Republic of Srpska.

The following table shows the turnover of financial leasing in Bosnia and Herzegovina (BH), by entities (the Republic of Srpska and the Federation of BH), and total turnover in Bosnia and Herzegovina, over ten years.

Table 1. Comparative indicators of financial leasing turnover in Bosnia and Herzegovina (000 EUR)

\begin{tabular}{|c|c|c|c|c|c|c|}
\hline Year & $\begin{array}{c}\text { The Republic } \\
\text { of Srpska }\end{array}$ & $\mathbf{( \% )}$ & $\begin{array}{c}\text { Federation of } \\
\text { Bosnia and } \\
\text { Herzegovina }\end{array}$ & $\mathbf{( \% )}$ & $\begin{array}{c}\text { Bosnia and } \\
\text { Herzegovina }\end{array}$ & $(\boldsymbol{\%})$ \\
\hline 2009 & 35,151 & 31.5 & 76,496 & 68.5 & 111,647 & 100 \\
\hline 2010 & 44,887 & 34.6 & 84,743 & 65.4 & 129,630 & 100 \\
\hline 2011 & 27,326 & 40.0 & 41,045 & 60.0 & 68,371 & 100 \\
\hline 2012 & 27,527 & 44.5 & 34,357 & 55.5 & 61,884 & 100 \\
\hline 2013 & 28,764 & 55.1 & 23,438 & 44.9 & 52,202 & 100 \\
\hline 2014 & 27,991 & 63.7 & 15,947 & 36.3 & 43,938 & 100 \\
\hline 2015 & 32,274 & 53.9 & 27,541 & 46.1 & 59,815 & 100 \\
\hline 2016 & 32,250 & 78.2 & 8,967 & 21.8 & 41,217 & 100 \\
\hline 2017 & 30,820 & 78.5 & 8,436 & 21.5 & 39,256 & 100 \\
\hline 2018 & 37,474 & 72.8 & 13,982 & 27.2 & 51,456 & 100 \\
\hline
\end{tabular}

Source: Banking Agencies from both entities (the Republic of Srpska, Federation of Bosnia and Herzegovina), Annual Reports 2009-2018

Chart 1: Financial leasing turnover in Bosnia and Herzegovina (000 EUR)

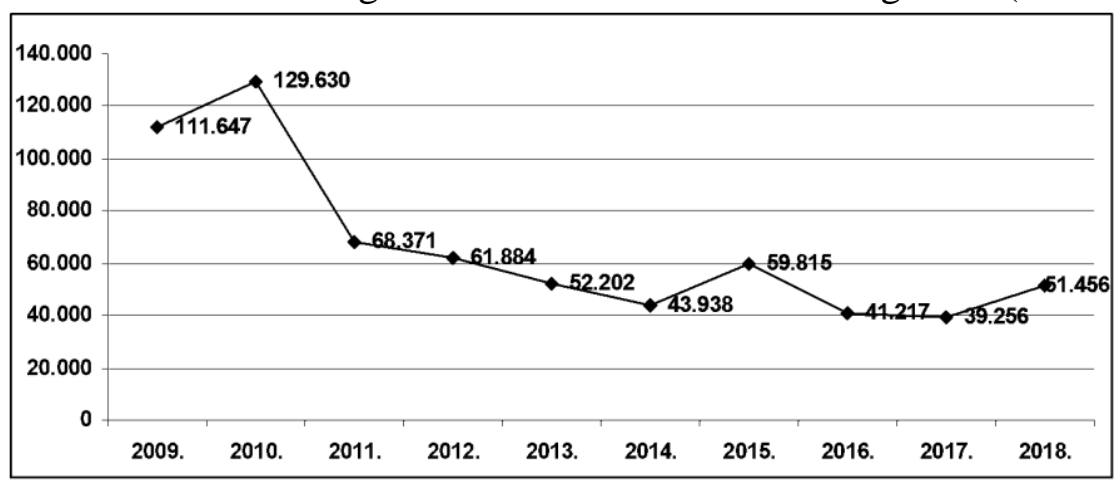

Source: Authors' processing 
Financial leasing at the financial market of Bosnia and Herzegovina registered a sharp decline in 2011 , amounting to 61.258 million euros or $47.26 \%$. The trend line of financial leasing maintained its decline until 2015, when a sharp increase of $36.13 \%$ was noted, only to be followed by a further decline in 2016 by $31.09 \%$.

Chart 2. Turnover in financial leasing by entities (RS, Federation of BH) (000 EUR)

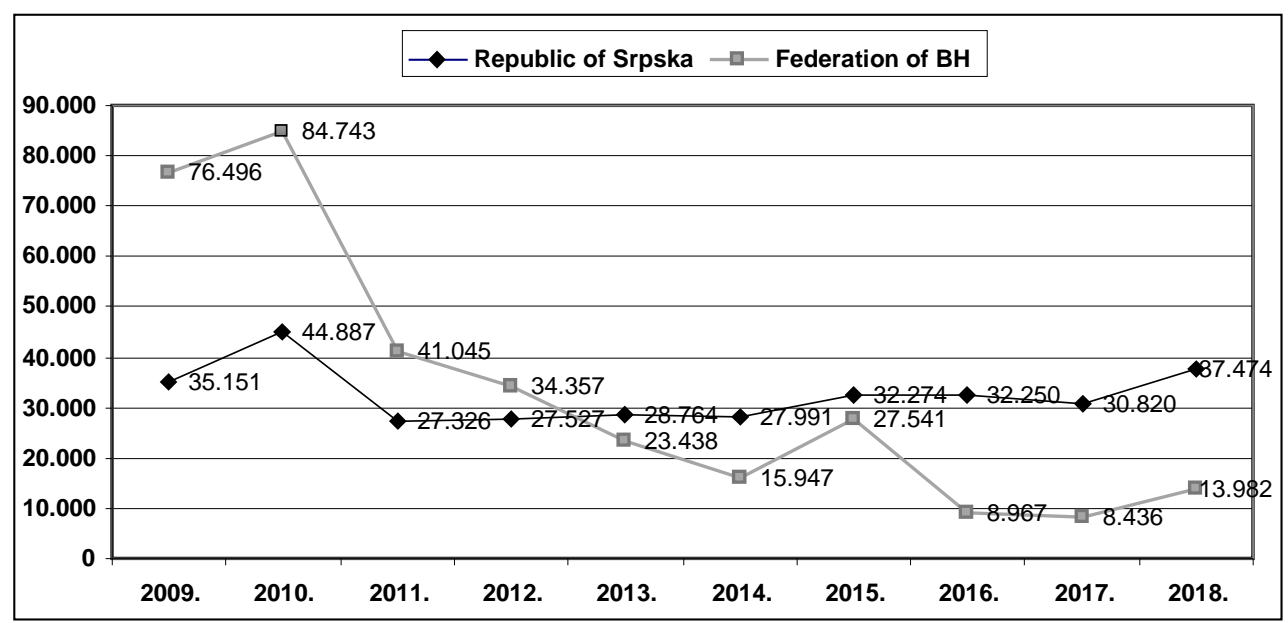

Source: Authors' processing

Based on the indicators presented (Chart 1), it can be concluded that financial leasing placements in the Republic of Srpska recorded a sharp decline in 2011 of 17.56 million euros or $39.12 \%$. After 2011, the trend line of financial leasing maintained a slight growth until 2018. In contrast to financial leasing arrangements in the Republic of Srpska, financial leasing in the Federation of BH recorded a sharp decline of 43.698 million euros or $51.56 \%$ in 2011 . The trend line of financial leasing registered a decline until 2015, when a slight increase was recorded, followed by a further decline in leasing investments in 2016.

Chart 3: Turnover in financial leasing by entities (RS, Federation of $\mathrm{BH})(\%)$

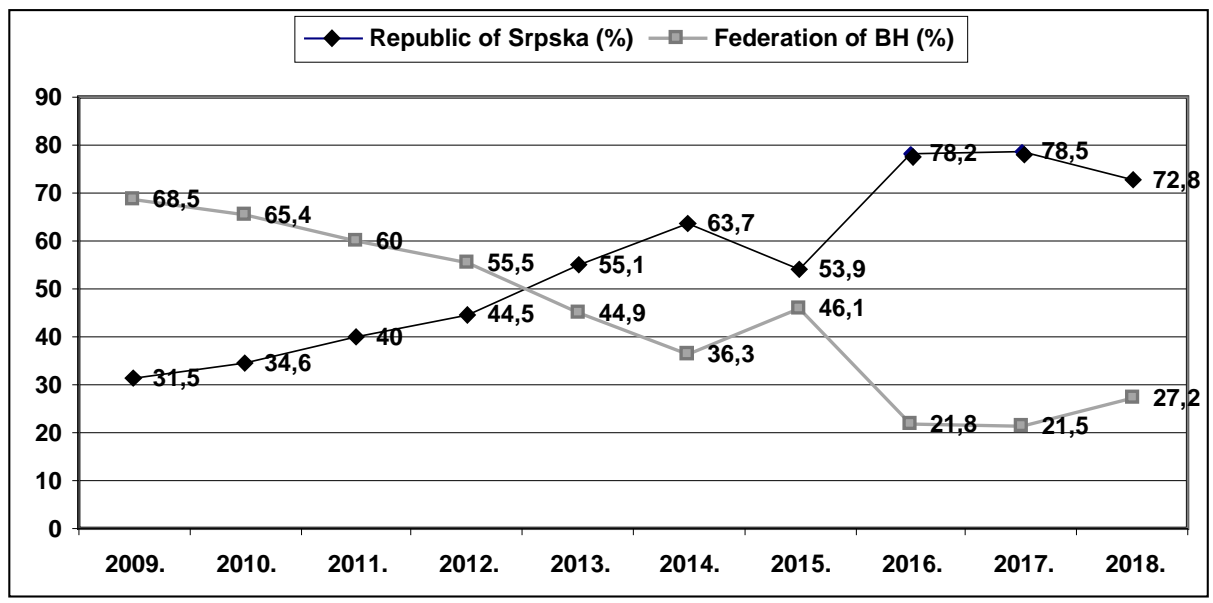

Source: Authors' processing

The percentage share of financial leasing arrangements in the Republic of Srpska registered a constant growth until 2015, concerning the total financial leasing arrangements in Bosnia and 
Herzegovina. On the other hand, the percentage share in financial leasing of the Federation of BH decreased until 2015 in the total financial leasing turnover in Bosnia and Herzegovina.

Based on the data from Table 1, it is evident that financial leasing was more present in the Republic of Srpska from 2013 to 2018 to financing through leasing in the Federation of BH. This leads to the conclusion that small and medium enterprises in the Federation of BH used a greater percentage of other sources to finance their business activities.

Despite this situation in the leasing market, it should be noted that innovations in leasing operations have not missed the $\mathrm{BH}$ leasing market, which is best confirmed by the activities of the European Bank for Reconstruction and Development (EBRD). Namely, the European Bank for Reconstruction and Development, as the largest investor in Central and Eastern Europe and the Commonwealth of Independent States, approved a credit line for small and medium enterprises in Bosnia and Herzegovina of 7 million euros through Raiffeisen Leasing Sarajevo. Since the beginning of 2007, this bank has financed small and medium enterprises in Bosnia and Herzegovina through leasing, by assisting in the implementation of 130 projects, in the amount of 1.8 billion euros (https://lat.rtrs.tv/vijesti/vijest.php?id=207892).

\section{ANALYTICAL APPROACH TO THE RELATIONS BETWEEN ECONOMIC INDICATORS IN BOSNIA AND HERZEGOVINA}

The analyzed economic indicators of Bosnia and Herzegovina are presented in Table 2 and represent different levels of a certain phenomenon by years.

Table 2. Economic indicators in Bosnia and Herzegovina (mil. EUR)

\begin{tabular}{|c|c|c|c|c|c|}
\hline YEAR & LEASING & GDP & EXPORT & IMPORT & FDI \\
\hline 2009 & 112 & 13,523 & 2,835 & 6,332 & 166 \\
\hline 2010 & 129 & 13,296 & 3,638 & 6,982 & 545 \\
\hline 2011 & 68 & 13,731 & 4,216 & 7,961 & 314 \\
\hline 2012 & 61 & 13,948 & 4,029 & 7,821 & 466 \\
\hline 2013 & 52 & 14,491 & 4,297 & 7,778 & 225 \\
\hline 2014 & 43 & 14,455 & 4,768 & 7,936 & 424 \\
\hline 2015 & 59 & 15,108 & 5,068 & 7,803 & 268 \\
\hline 2016 & 42 & 15,914 & 5,429 & 8,017 & 236 \\
\hline 2017 & 39 & 16,671 & 6,434 & 9,077 & 414 \\
\hline 2018 & 51 & 17,453 & 6,956 & 9,556 & 409 \\
\hline
\end{tabular}

Source: Council of Ministers of Bosnia and Herzegovina, Directorate for Economic Planning, Economic Trends - Annual Reports 2009 - 2018

In order to assess the relationship between the observed phenomena, as well as their mutual influence, it is necessary to apply correlation and regression analysis. The correlation analysis should indicate whether there is a quantitative matching between the observed phenomena, while the regression analysis assessed the level of impact of variables such as leasing, exports, imports, and foreign direct investment (FDI) on the gross domestic product (GDP). The results of the correlation analysis are given in Table 3.

Given that the impact of leasing, exports, imports, and foreign direct investment on GDP will be assessed in the remainder of the paper, it was necessary to analyze how these variables are related to the GDP variable (Table 3). As the variables do not deviate from the normal distribution, the Pearson correlation coefficient was used and the results indicate that all 
variables, except for FDI, are in a statistically significant correlation with GDP. Likewise, it is necessary to stress that the leasing variable is negatively correlated with GDP, thus indicating that the growth of one variable is associated with a decrease in the other variable $(\rho=-0.666)$. Apart from this connection, it is evident that a direct and strong correlation is established by the variables export and import with GDP $(\rho=0.962$ and $\rho=0.875)$. It is important to note that there is an extremely strong correlation between export and import. Such correlation is direct and indicates that the growth of one implies the growth of the other variable $(\rho=0.951)$. Both import and export establish a statistically significant correlation with leasing, but this relation is indirect, meaning that the increase of one variable implies the decrease of another.

Table 3. Correlation analysis

\begin{tabular}{|l|l|r|r|r|r|r|}
\hline \multicolumn{7}{|c|}{ Correlations } \\
\hline LEASING & $\begin{array}{l}\text { Pearson } \\
\text { Correlation }\end{array}$ & 1 & $-0.666^{*}$ & $-0.714^{*}$ & $-0.747 *$ & 0.116 \\
\hline GDP & $\begin{array}{l}\text { Pearson } \\
\text { Correlation }\end{array}$ & $-0.666^{*}$ & 1.000 & $0.962^{* *}$ & $0.875^{* *}$ & 0.013 \\
\hline EXPORT & $\begin{array}{l}\text { Pearson } \\
\text { Correlation }\end{array}$ & $-0.714^{*}$ & $0.962^{* *}$ & 1.000 & $0.951 * *$ & 0.191 \\
\hline IMPORT & $\begin{array}{l}\text { Pearson } \\
\text { Correlation }\end{array}$ & $-0.747^{*}$ & $0.875^{* *}$ & $0.951^{* *}$ & 1.000 & 0.283 \\
\hline FDI & $\begin{array}{l}\text { Pearson } \\
\text { Correlation }\end{array}$ & 0.116 & 0.013 & 0.191 & 0.283 & 1.000 \\
\hline
\end{tabular}

Source: Authors' processing

In addition to the correlation analysis, a regression analysis was performed, aimed to show whether the changes in these four variables have an impact (and to what extent) in explaining the changes in the GDP variable. On the account of the above, a multiple regression was applied in which GDP was the dependent variable, whereas the independent (explanatory) ones were leasing, export, import, and FDI. Due to the strong correlation between the variables of export and import, it was necessary to exclude one of them from further analysis, as multicollinearity would occur otherwise. With this in mind, leasing, export, and FDI remained explanatory variables in further analysis. The results of the regression analysis are given below:

Table 4. Coefficient of determination

\begin{tabular}{|l|r|r|r|c|}
\hline \multicolumn{5}{|c|}{ Model Summary } \\
\hline Model & R & R Square & $\begin{array}{c}\text { Adjusted R } \\
\text { Square }\end{array}$ & $\begin{array}{c}\text { Std. Error of the } \\
\text { Estimate }\end{array}$ \\
\hline 1 & $0.982^{\mathrm{a}}$ & 0.965 & 0.948 & 321.780 \\
\hline a. Predictors (Constant), FDI, LEASING, EXPORT & & \\
\hline
\end{tabular}

Source: Authors' processing

The table above shows the level of variation of the dependent variable which is explained by the observed model. In this case, this level is extremely high and it can be said that about $94.8 \%$ of the GDP variation is explained employing this model which includes the three aforementioned variables.

The above indicator was tested by the $\mathrm{F}$ test, and the results obtained indicate that it is statistically significant $(F=55.36 ; p$ value $=0.000)$. 
Table 5. Statistical significance indicators of the model

\begin{tabular}{|c|c|c|c|c|c|c|}
\hline \multicolumn{7}{|c|}{ ANOVA $^{\mathbf{a}}$} \\
\hline \multicolumn{2}{|c|}{ Model } & $\begin{array}{c}\text { Sum of } \\
\text { Squares }\end{array}$ & df & $\begin{array}{c}\text { Mean } \\
\text { Square }\end{array}$ & $\mathbf{F}$ & Sig. \\
\hline \multirow{3}{*}{1} & Regression & 17194762.652 & 3 & 5731587.551 & 55.355 & $0.000 \mathrm{~b}$ \\
\hline & Residual & 621253.348 & 6 & 103542.225 & & \\
\hline & Total & 17816016.000 & 9 & & & \\
\hline \multicolumn{7}{|c|}{ a. Dependent Variable: GDP } \\
\hline \multicolumn{7}{|c|}{ b. Predictors (Constant), FDI, LEASING, EXPORT } \\
\hline
\end{tabular}

Source: Authors' processing

By calculating the coefficients of multiple linear regression, more information will be obtained on the statistical significance of certain coefficients and their impact on GDP.

Table 6. Multiple linear regression coefficients

\begin{tabular}{|c|c|c|c|c|c|c|c|c|c|c|c|}
\hline & \multicolumn{11}{|c|}{ Coefficients $^{\mathrm{a}}$} \\
\hline & \multirow{2}{*}{ Model } & \multicolumn{2}{|c|}{$\begin{array}{l}\text { Unstandardized } \\
\text { Coefficients }\end{array}$} & \multirow{2}{*}{\begin{tabular}{|c|c}
$\begin{array}{c}\text { Standa } \\
\text { rdized } \\
\text { Coeffic } \\
\text { ients }\end{array}$ \\
Beta \\
\end{tabular}} & \multirow{2}{*}{$\mathbf{t}$} & \multirow{2}{*}{ Sig. } & \multicolumn{3}{|c|}{ Correlations } & \multicolumn{2}{|c|}{$\begin{array}{l}\text { Collinearity } \\
\text { Statistics }\end{array}$} \\
\hline & & B & $\begin{array}{c}\text { Std. } \\
\text { Error }\end{array}$ & & & & $\begin{array}{l}\text { Zero- } \\
\text { order }\end{array}$ & Partial & Part: & $\begin{array}{l}\text { Toler } \\
\text { ance }\end{array}$ & VIF \\
\hline & (Constant) & 9314.165 & 855.952 & & 10.882 & 0.000 & & & & & \\
\hline & LEASING & 7.057 & 5.387 & 0.153 & 1.310 & 0.238 & -0.666 & 0.472 & 0.100 & 0.424 & 2.359 \\
\hline & EXPORT & 1.247 & 0.133 & 1.113 & 9.392 & 0.000 & 0.962 & 0.968 & 0.716 & 0.414 & 2.415 \\
\hline & FDI & -2.494 & 0.959 & -0.217 & -2.600 & 0.041 & 0.013 & -0.728 & -0.198 & 0.834 & 1.199 \\
\hline
\end{tabular}

Source: Authors' processing

The results presented in Table 6 , indicate that the two coefficients are statistically significant and uniquely contribute to the prediction of the dependent variable. The coefficients in question are B2 ( $t$ test $=9.392 ; p$ value $=0.000)$ and B3 ( $t$ test $=-2.600 ; p$ value $=0.041)$, respectively, i.e. the variables export and FDI. In contrast, the leasing variable lacks a statistically significant coefficient B1 and its contribution cannot be treated as significant and unique. In the column of standardized coefficients (beta) it is evident that the export variable has more than five times higher contribution to the explanation of GDP than variable FDI $(1.113>|-0.217|)$. Therefore, it can be said that in the observed model, a unique and statistically significant contribution to the elaboration of GDP is given by export and FDI, while the leasing variable bears no statistical significance.

\section{FINANCIAL LEASING IN THE FUNCTION OF INVESTMENT DECISION- MAKING OF SMALL AND MEDIUM ENTERPRISES IN BOSNIA AND HERZEGOVINA}

In developed western countries, leasing plays a very important role in economic development, and especially in the development of small and medium enterprises. The purpose of leasing here is, above all, the development of the economy, as evidenced by over $90 \%$ of leasing placements aimed at legal entities (small and medium enterprises). Small and medium-sized enterprises (SMEs) that require working capital, and that borrow funds on that account, leasing arrangements are a very convenient and useful option. Leasing arrangements, which make up 
over $20 \%$ and in some cases over $30 \%$ of the total equipment procurement in the world, allow for a simpler and cheaper way of purchasing equipment. These arrangements are particularly applicable when an entity is faced with insufficient equity and bank loans that are still unfavorable. One of the greatest advantages of financial leasing is the effective protection of creditors, which makes leasing competitive in relation to other financial arrangements and bank loans (Subotić, Erceg and Mitrović, 2018).

Banks in Bosnia and Herzegovina require high loan collateral, thus transferring as much risk as possible onto the borrower. The following is normally used as collateral: deposits, guarantees of other commercial banks, real estate, debtors' promissory notes, and other forms of loan collateral. An additional problem for companies when applying for this type of loan is the extensive documentation that is normally an integral part of the procedure. The amount of the loan mainly depends on the creditworthiness of the company.

Small and medium enterprises (SMEs) in Bosnia and Herzegovina are increasingly facing the problem where the necessity for financial assets exceeds the amount of newly created money accumulation remaining at their disposal. Such events and developments cause them to increasingly direct their financial demand to banks and bank loans. By approving and placing loans, banks enable small and medium-sized enterprises to maintain liquidity, permanent continuity, and business stability (Subotić, Erceg and Mitrović, 2018).

Table 7. Loan placement in Bosnia and Herzegovina (000 EUR)

\begin{tabular}{|c|c|c|c|c|c|c|c|}
\hline \multirow[b]{2}{*}{ Year } & \multicolumn{3}{|c|}{$\begin{array}{l}\text { THE REPUBLIC OF } \\
\text { SRPSKA (RS) }\end{array}$} & \multicolumn{3}{|c|}{$\begin{array}{c}\text { FEDERATION OF BOSNIA AND } \\
\text { HERZEGOVINA } \\
\text { (Federation of BH) }\end{array}$} & \multirow{2}{*}{$\begin{array}{c}\text { TOTAL } \\
\text { BOSNIA } \\
\text { AND } \\
\text { HERZEG } \\
\text { OVINA }\end{array}$} \\
\hline & $\begin{array}{c}\text { Public } \\
\text { enterprises }\end{array}$ & E & $\begin{array}{c}\text { Total } \\
\text { RS }\end{array}$ & $\begin{array}{c}\text { Public } \\
\text { enterprises }\end{array}$ & SME & $\begin{array}{l}\text { Total } \\
\text { Federation } \\
\text { of BH }\end{array}$ & \\
\hline 2009 & & & & & 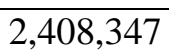 & $2,502,708$ & \\
\hline 2010 & & & & & $2,469,451$ & & \\
\hline 2011 & & & & & $2,521,942$ & $2,554,017$ & 3,7 \\
\hline 2012 & & & & & $2,636,594$ & $2,765,431$ & 010 \\
\hline 201 & & & & & & & \\
\hline 201 & & & & & 7 & & \\
\hline 2015 & & & & & & & \\
\hline 2016 & & & & & & & 4,0 \\
\hline 2017 & & & & 107,929 & $3,228,491$ & $3,336,420$ & $4,398,199$ \\
\hline 2018 & 137,705 & 939,151 & $1,076,856$ & 164,868 & $3,397,765$ & $3,562,633$ & $4,639,489$ \\
\hline
\end{tabular}

Source: Banking Agencies from both entities (the Republic of Srpska, Federation of Bosnia and Herzegovina), Annual Reports 2009-2018

A closer look at credit placements in public and state-owned enterprises, as well as in small and medium enterprises (SMEs) in Bosnia and Herzegovina (Table 6), allows us to register a growth tendency in the period from 2009 to 2018. Total credit placements in Bosnia and Herzegovina over the same time period also recorded growth (Chart 4).

Loans to small and medium-sized enterprises (SMEs) in Bosnia and Herzegovina followed the growth of total loans by year, as presented in Chart 5. 
Chart 4. Loan placement in Bosnia and Herzegovina (mil. EUR)

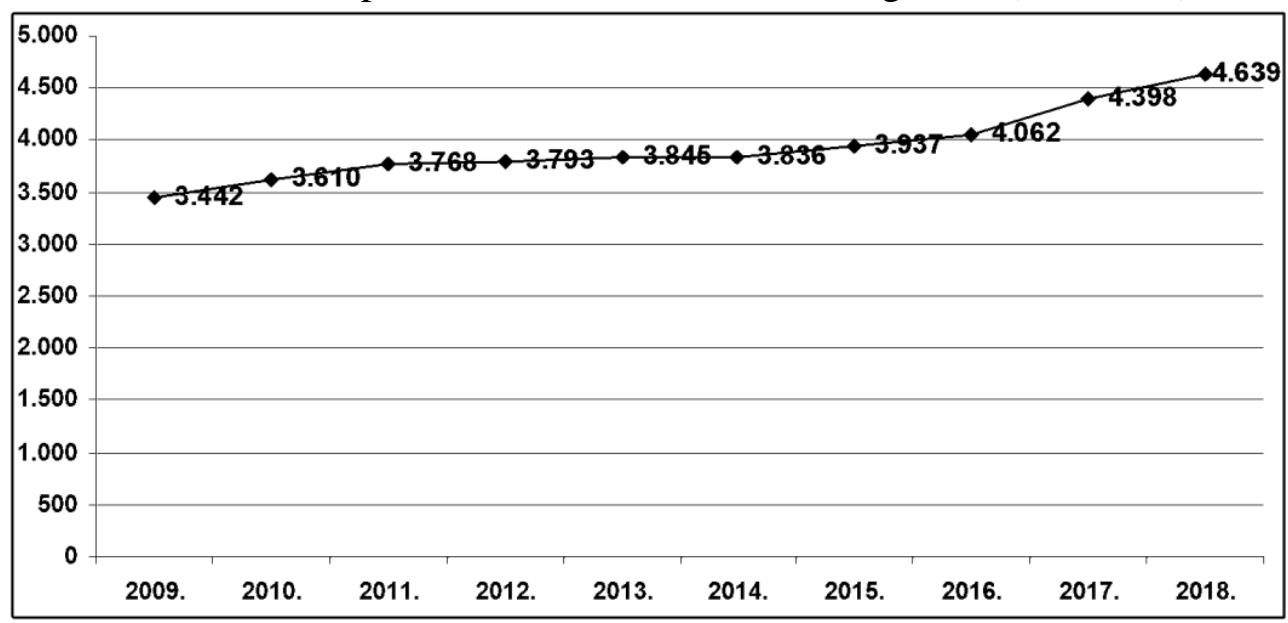

Source: Authors' processing

Chart 5. SME Loan placement in Bosnia and Herzegovina (mil. EUR)

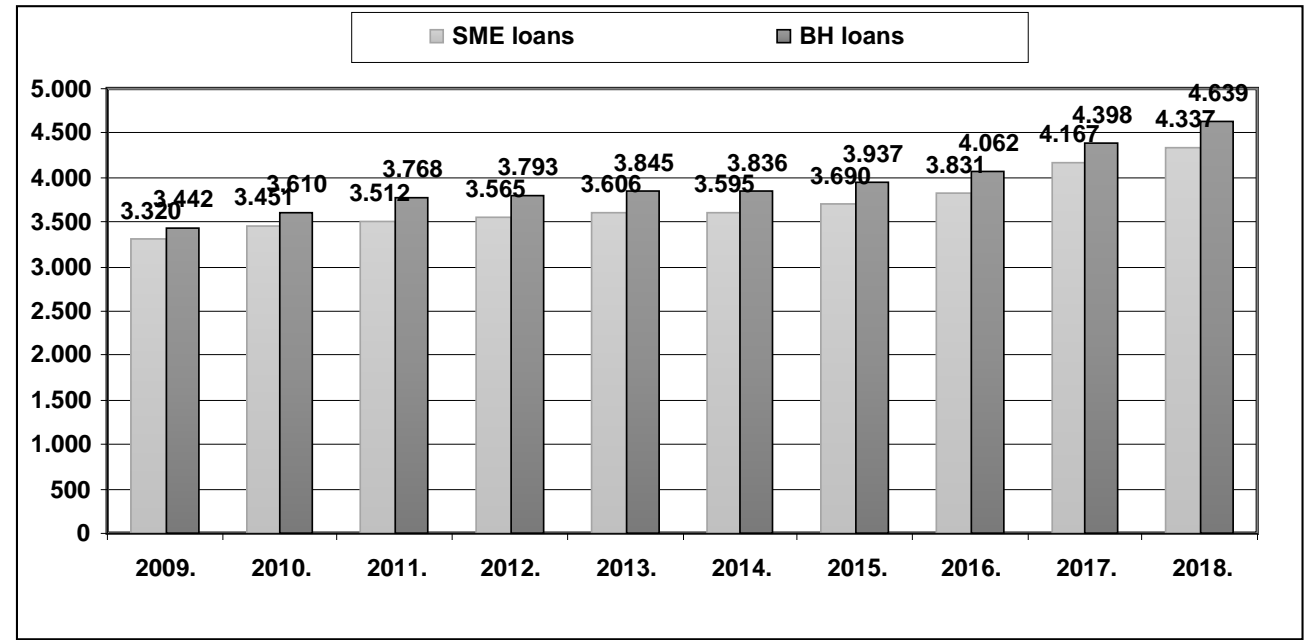

Source: Authors' processing

Chart 6. Loan placement in Bosnia and Herzegovina (mil. EUR)

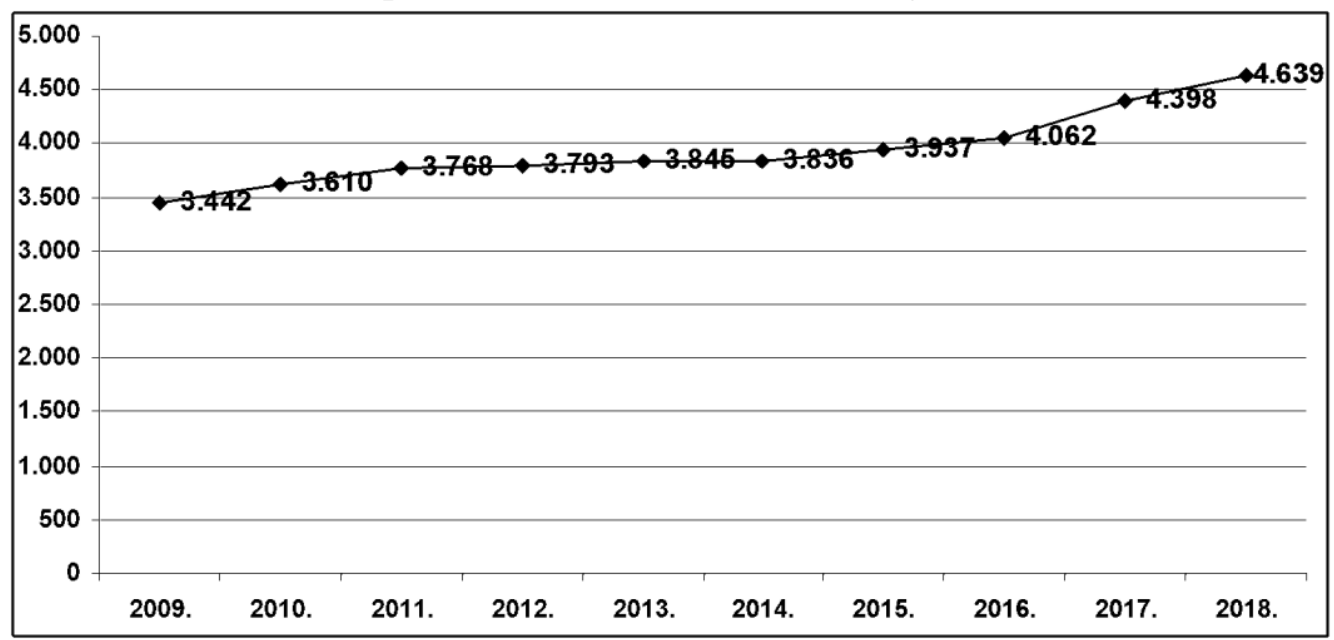

Source: Authors' processing 
Chart 7. Financial Leasing in Bosnia and Herzegovina (mil. EUR)

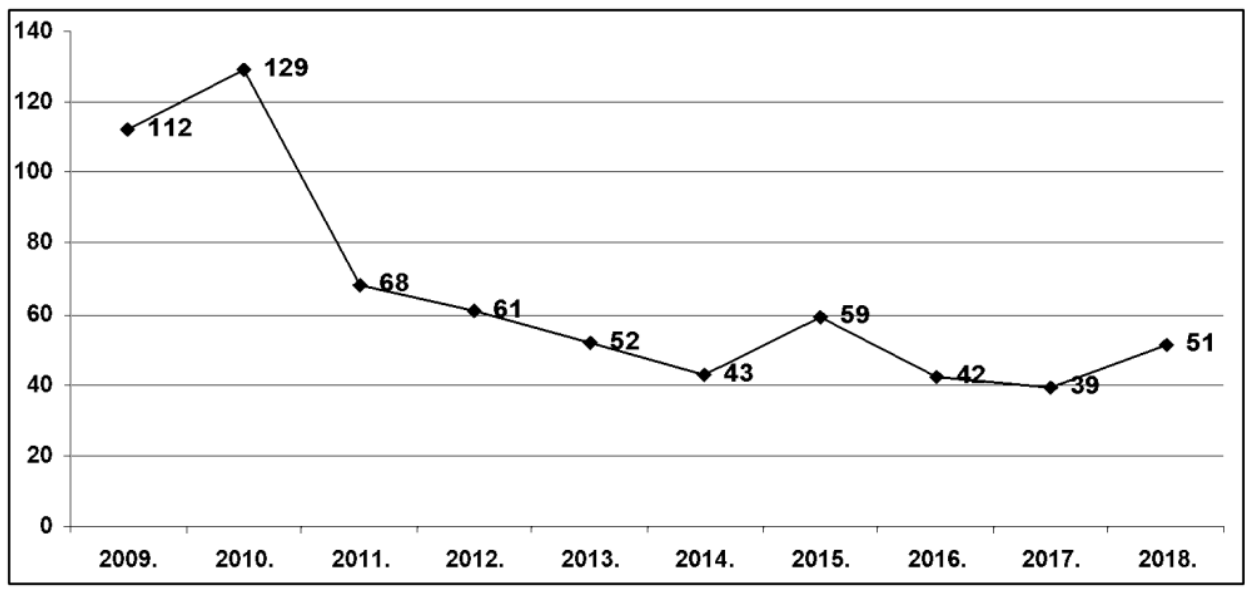

Source: Authors' processing

Chart 8. Leasing in Europe (bn. EUR)

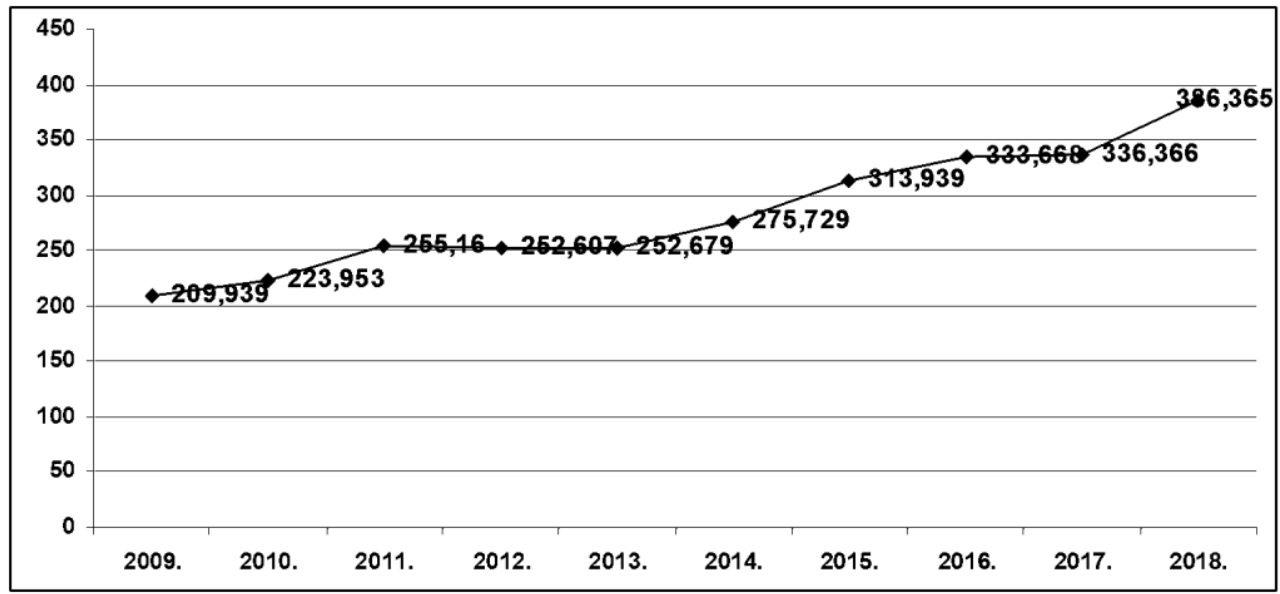

Source: http://www.leaseurope.org

The results of the comparative analysis of the indicators presented in the charts above indicate that credit placements in Bosnia and Herzegovina grew permanently from 2009 to 2018. Loans to small and medium-sized enterprises (SMEs) in Bosnia and Herzegovina also registered a permanent annual growth and follow the growth of total credit placements. In contrast to credit placements, financial leasing arrangements in Bosnia and Herzegovina have recorded a permanent decline since 2011, except a slight increase in 2015 (Chart 7). On the other hand, leasing arrangements in European countries record a permanent annual growth from 2009 to 2018. That is, the line of leasing trend in Bosnia and Herzegovina keeps declining, except for 2015 and 2018, while the leasing trend line in European countries maintains slight growth.

\section{CONCLUSION}

The results of this research showed that the financial leasing market in Bosnia and Herzegovina is quite scarce and underdeveloped, while financial leasing activities are performed by seven different leasing companies located in the Federation of Bosnia and Herzegovina. In the Republic of Srpska, as the second entity in Bosnia and Herzegovina, there are no entities registered for financial leasing operations. Despite this fact, the financial leasing market in the Republic of Srpska registered a slight growth in the period from 2011 to 2018. In contrast to financial leasing arrangements in the Republic of Srpska, financial leasing in the Federation of 
Bosnia and Herzegovina registered a decline in the period from 2011 to 2015, therefore making the downward-upward trend line of financial leasing in this entity.

In order to assess the relationship between economic indicators in Bosnia and Herzegovina, and their mutual effect and influence, a correlation and regression analysis were used. Correlation analysis allowed to determine the quantitative matching between the observed phenomena, while the regression analysis assessed the level of influence of the following variables: leasing, export, import, and foreign direct investment (FDI) onto the value of the gross domestic product (GDP). By using the Pearson correlation coefficient, the results that were obtained indicated that all variables, except FDI, were statistically significantly correlated with GDP. Variable leasing is negatively correlated with GDP, indicating that the growth of one variable is related to the decrease of another variable. On the other hand, a direct and strong correlation of variables such as export and import with GDP was observed. It is important to note that a statistically significant indirect relation is achieved both between import \& export and leasing, meaning that the growth of one variable implies the decline of another variable and vice versa. The results of the regression analysis indicate that two coefficients $\left(B_{2}\right.$ and $\left.B_{3}\right)$ are statistically significant, giving a unique contribution to the prediction of the dependent variable, namely the variables of export and FDI. In contrast, the leasing variable has no statistically significant coefficient $\mathrm{B}_{1}$ and its contribution cannot be treated as significant and unique. Based on the above, it can be concluded that in the observed model, a unique and statistically significant contribution to the elaboration of GDP is provided primarily by export and FDI, while the leasing variable has no statistical significance.

A comparative analysis of financial leasing and loans, as a form of financing, indicates the fact that financial leasing was not in the function of deciding and making strategic decisions to replace credit arrangements by this distinct and more favorable form of financing business activities in Bosnia and Herzegovina. Namely, while a permanent decline in leasing arrangements has been registered over the last few years, credit placements have been growing at a much faster rate. In contrast to leasing arrangements in Bosnia and Herzegovina, which maintained their tendency to decline over the recent years, leasing financing in developed European countries has been growing steadily, which was particularly notable in the period from 2015 to 2018 .

By summarizing the results of financial leasing market research, as well as of statistical indicators of correlation and regression analysis, together with the results of comparative analysis of financial leasing and loans, it can be said that the impact of financial leasing on SME development and economic development of Bosnia and Herzegovina over the observed ten year period was negligible and insignificant.

\section{REFERENCES}

Banking Agency of Federation of BH (2009-2018). Annual reports, Sarajevo.

Banking Agency of the Republic of Srpska (2009-2018). Annual reports, Banja Luka

Central bank of BH (2018). Annual reports, Sarajevo.

Council of Ministers of Bosnia and Herzegovina, Directorate for Economic Planning (2009 2018) Economic Trends-Annual reports, Sarajevo.

Subotić S, Erceg Ž, Mitrović G (2018). Finansijski lizing u funkciji strategijskog odlučivanja o finansiranju poslovne aktivnosti (eng. Financial leasing in the Function of Strategic Decision-Making - on Financing Business Activities), Poslovni konsultant/Business Consultant No.76., Finconsult Tuzla, Tuzla. 
Vukmirović N (2007). Kreiranje povoljnijeg ekonomsko-preduzetničkog ambijenta (eng. Creating a more favorable economic and entrepreneurial environment), Proceedings of the round table "Ambience for Entrepreneurship", State Agency for Development of Small and Medium Enterprises, Banja Luka.

Vunjak N (2005). Finansijski menadžment - Poslovne finansije (eng. Financial Management Business Finance), Proleter Bečej, Faculty of Economics in Subotica, Subotica.

https://lat.rtrs.tv/vijesti/vijest.php?id=207892

http://www.leaseurope.org 